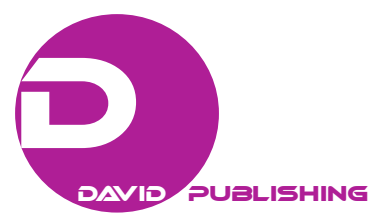

\title{
Tourism Development in UNESCO Natural Heritage Sites- The Case of Sicilian Volcanic Sites: Mount Etna and Aeolian
} Islands

\author{
Giovanni Ruggieri \\ University of Palermo, Palermo, Italy \\ Francisco J. Calderon Vazquez \\ University of Malaga, Malaga, Spain
}

\begin{abstract}
Local development often depends on tourism, especially in fragile contexts like islands which represent a special cluster and are the best cases to be analyzed in order to highlight positive and negative aspects of economic development driven by tourism. A sustainable development approach should be taken in account and the UNESCO brand plays a fundamental role in this sense. The aim of this paper is to analyze the link between tourism supply and the growth of tourism demand in the case of UNESCO sites through multivariate regression analysis. The results show a correlation between the variables considered. But the actual structure of supply is still built on conventional sea tourism and is not yet organized to host and attract tourism demand connected with the UNESCO active volcano area. The UNESCO brand could guarantee a new approach for local tourism development if associated with a specific tourism supply structure.
\end{abstract}

Keywords: development, islands, tourism, sustainability, analysis

\section{Introduction and Literature Review}

Volcanoes, in particular those that are still active, and their wide variety of landscapes and textures are important factors to draw tourists (Dóniz Páez, 2014; Dóniz Páez, Guillén, Becerra Ramírez, \& Kereszturi, 2010). This is not a recent, but a historical trend which is extensively documented since the time of the Grand Tour (Erfurt-Cooper, 2010; 2011; Sigurdsson \& Lopes, 2000). There is, therefore, a clear relationship between tourism and volcanoes. Today, volcanic tourism is a very popular form of tourism "becoming increasingly popular in many regions of the world” (Heggie, 2009, p. 260), as proven the growing number of visitors registered in recent years by many sources (Heggie, 2009; Farsani, Coelho, \& Costa, 2011).

First of all, tourism on volcanoes is synergic with other forms of tourism, such as spa tourism (Sigurdsson \& Lopes, 2000; Erfurt-Cooper \& M. Cooper, 2010), ecotourism, and scientific tourism (Mollaei, Torshizian, \& Sharifi, 2010; Sheth, Ray, Bhutani, Kumar, \& Awasthi, 2010; Toulkeridis \& Zak, 2010). Secondly, it includes

Giovanni Ruggieri, adjunct professor in Tourism Economics, Department SEAS, University of Palermo, Palermo, Italy.

Francisco J. Calderon Vazquez, associated professor in Applied Economics, Department of Applied Economics, University of Malaga (UMA), Malaga, Spain.

Correspondence concerning this article should be addressed to Giovanni Ruggieri, Department SEAS, University of Palermo, Building 13, Viale delle Scienze, Palermo 90128, Italy. 
numerous recreational activities such as skiing, excursions, trekking, climbing, and camping (Lopes-Gautier, 2010). Often, near these areas, there are thermal springs and resorts that offer wellness and personal care services. A third reason is linked to the increasing ease of access to these destinations both from a physical and economic point of view. Finally, one last reason is the growing interest in the natural environment and the related growth in demand for visits to national parks, geoparks, and natural sites on the UNESCO World Heritage List.

Inclusion on the World Heritage List (WHL) is clearly an event with a significant impact on the media, though in actual fact it has been established to safeguard cultural and natural heritage and not for marketing purposes. Heritage, whether cultural or natural, is, on the one hand, the fundamental, identity-building element of a place and, on the other, the essential structural component that allows speaking of destination, supply, and demand. Being an essential tourism resource, it is absolutely necessary to provide for forms of protection and conservation. Hence the huge importance of the UNESCO World Heritage List (UNESCO, 2005), is considered as "the most effective international legal instrument for the protection of the cultural and natural heritage” (Strasser, 2002, p. 215). As regards volcanoes, there are as many as 24 volcanic areas included among the UNESCO natural heritage sites ${ }^{1}$ and the list is expected to become longer in coming years.

The general aim of this paper is to analyze the link between tourism supply and growth in terms of tourism demand in the case of UNESCO natural heritage sites in Sicily, i.e., the Aeolian Islands and Mount Etna, famous and globally recognized volcanic areas that include two legendary volcanoes: Mount Etna and Stromboli, both included on the WHL in 2000 (Aeolian Islands), and in 2013 (Mount Etna). We propose a multivariate regression analysis, in order to investigate the relationship between the structure of tourism supply and the demand performances in terms of overnights and average expenditure.

So, the current work aims, on the one hand, to determine whether the WHL is fostering tourism demand, in the Aeolian Islands and in the Mount Etna area, by trying to find an answer to the following questions: How is tourism linked to natural heritage, especially volcanoes, at the Sicilian sites? What are their results in terms of increased tourist activity and demand? Are Sicilian volcanoes attracting increasingly tourists? And, if so, how are they doing so? On the other hand, the operational goal consists in providing information and suggestions on how to increase supply (if necessary) in qualitative and quantitative terms (Frediani, 2001) so as to boost competitiveness.

\section{Methodology}

The study starts from an analysis carried out on UNESCO World Heritage sites in Sicily to identify the structure of supply and the variables of tourist demand.

In order to verify the existence of a link between a given aspect of the local tourism supply in quantitative terms and the performance recorded at the site, models based on the calculation of regressions were used. In particular, a specific statistical processing software allowed us to determine the values of regression and

\footnotetext{
1 Yellowstone (USA); Hawaii Volcanoes National Park (Big Island, Hawaii); Aeolian Islands, Moun Etna and The Archaeological Areas of Pompei and Ercolano (Italy); Sangay National Park and Galápagos Islands (Ecuador); Volcanoes of Kamchatka (Russia) Lord Howe Island, Macquarie Island, Central Eastern Rainforest Reserves (Australia) and Heard and McDonald Islands (Australian Territory), Tongariro National Park (New Zealand), Mount Kenya and Lake Turkana National Parks (Kenya); Kilimanjaro National Park and Ngorongoro Conservation Area (Tanzania); Virunga and Kahuzi-Biega Nationals Parks (Democratic Republic of Congo); Air and Ténéré Natural Reserves (Niger); Gros Morne National Park (Canada) and Teide National Park (Canary Islands, Spain).
} 
correlation coefficients with the aim of assessing whether a link exists between the structure of the local tourism supply and the performance recorded in terms of overnights and generated tourist spending.

Since the results deriving from the application Linear Regression Model present some distortions in the results, a more in-depth analysis appears to be necessary and Curve Estimation was chosen from among the available regression models. This instrument allows us to approximate curves to the punctual data collected in order to show their trends and make predictions. The analysis was carried out by assuming a linear approximation function and a growth function whose reference values are shown in the tables below. The analysis was also carried out considering two dependent variables, i.e., Overnights and Tourist Spending.

The last step of the analysis leads to the calculation of the Pearson correlations between the spending variable and the various types of enterprises operating in the tourism sector.

\section{Theoretical Aspects}

According to Dóniz Páez (2014), though the relationship between tourism and volcanoes dated back centuries, studies on the development of tourism in volcanic areas are relatively recent. This prevents creating a significant theoretical framework. The available studies tend to focus on tangible and "applied" aspects of the phenomenon, addressing, on the one hand, the development of the geographical and sustainability issues concerning tourism in volcanic areas (guides, itineraries, localization, etc.) from a global perspective (Erfurt-Cooper \& M. Cooper, 2010; UNESCO, 2006a; 2006b; Gray, 2008), and from a local perspective (Carracedo, 2006; Dóniz Páez, 2014; El Wartiti, Malaki, Zahraoui, Di Gregorio, \& De Waele, 2009; O’Connor, 2008; Mc Keever, Larwood, \& McKirdy, 2006). On the other, we have found a wide range of research on the risks to human health of tourism in volcanic areas (Heggie, 2009; Lane, Larwood, \& McKirdy, 2009; Behncke, 2009; Hansell \& Oppenheimer, 2009). Finally, studies concerning the impact of volcanic tourism (as part of what is called geotourism) in local and rural development both at a generic level and in specific geological areas are appearing more frequently (Dowling, 2009; Farsani, Coelho, \& Costa, 2009; Gerner, Rybár, Engel, \& Domaracká, 2009; Hose, 2007; El Wartiti et al., 2009).

As such, volcanic tourism could be framed in the context of geotourism (Heggie, 2009; Erfurt-Cooper \& M. Cooper, 2010; National Geographic Society, 2005; Mc Keever, Zouros, \& Patzak, 2010) which can be described with the definition used by Newsome and Dowling (2010, p. 3) as "a form of natural area tourism that specifically focuses on geology and landscape." ${ }^{2}$ It is not possible to exclude the appearance of geoparks (UNESCO, 2006a, 2006b; Patzak \& Eder, 1998) from geotourism, given that these geoparks are often established in areas with slow economic development, such as rural areas, islands, and small islands, and are major opportunities for the development of a rural or island community (Zouros \& Martini, 2003), thus encouraging volcanic areas to specialize in hosting and serving this new segment of visitors. Though there are 48 geoparks included on the UNESCO list, very few can be considered strictly volcanic (Joyce, 2010). There is undoubtedly great pressure to be included on this list and therefore we can assume that there will be a sustained increase in the number of volcanic sites in the geoparks list (Joyce, 2010).

The relationship between the WHL and tourism has been the subject of a great deal of attention in the international literature and has been addressed from different points of view and approaches. In this paper,

\footnotetext{
${ }^{2}$ And it continues: "It promotes tourism to geo-sites and the conservation of geo-diversity and an understanding of earth sciences through appreciation and learning. This is achieved through independent visits to geological features, use of geo-trails and view points, guided tours, geo-activities and patronage of geo-site visitor centres.”
} 
we will assess whether the UNESCO mark is able to influence the total number of visitors to the area considered in our case, namely the volcanic area of Mount Etna and the Aeolian Islands. Despite the fact that the WHL has been created to protect the cultural and natural heritage, the media impact associated with inclusion of a site is remarkable. Inclusion on this list is a huge honor and the greatest accolade that a protected area can receive (Shackley, 1998; Timothy \& Boyd, 2003). The event, therefore, receives great media's attention in the country of the site (Frey, Pamini, \& Steiner, 2013), as well as broad coverage on the Internet and social networks. In this regard, the inclusion on the WHL is a propagator of information for a large number of entities and benefits from even greater dissemination through social networks and the Internet in general. Therefore, one might posit a positive correlation between inclusion in the WHL and a significant increase in tourist flows to these places (Lazzarotti, 2000; Yang, Lin, \& Han, 2009; Van der Aa, 2005, Mondini \& Re, 2012; Lo Piccolo \& Leone, 2014). So, it comes as no surprise that many UNESCO sites have also become renowned tourist destinations (Cuccia, Guccio, \& Rizzo, 2014; Patuelli, Mussoni, \& Candela, 2012; Roh, Bak, \& Min, 2015).

In this regard, the UNESCO mark could contribute effectively to transforming a WHL site into a tourist destination. These aspects are at the center of a dispute that has not yet ebbed away, generating as they have a debate between three fundamental positions. On the one hand, there are scholars who argue that the WHL neither stimulates tourist demand, nor is it able to generate a significant impact on the ability to attract tourist flows (Rodwell, 2002; Lai, 2013; Poria, Reichel, \& Cohen, 2013). On the other, you have those who maintain that the WHL fuels tourist demand and not only, being one of the most powerful attractors capable of drawing significant tourist flows to a site through its significant range of action, greatly contributing to its standing as a tourist destination (Shackley, 1998; Buckley, 2004; Fredman, Friberg, \& Emmeling, 2007; Tucker \& Emge, 2010; Yang et al., 2010). Finally, the core of researchers defined as "neutral", since their investigations have not provided a clear answer in this regard (Timothy \& Boyd, 2003; Leask \& Fyall, 2006; Arezki, Cherif, \& Piotrowski, 2009; Cellini, 2011; Frey \& Steiner, 2011). For them, the WHL may be an indirect or passive inductor of tourism, especially in little known or simply unknown places.

\section{The Case Study-Analysis and Results}

The study starts from an analysis carried out on UNESCO World Heritage sites in Sicily to identify the structure of supply and the variables of tourist demand and to study the relationships existing between them.

In particular, the analysis aims at verifying the link existing between a given aspect of the local tourism supply in quantitative terms and the performance recorded at the site.

Models based on the calculation of multivariate regressions were used for the purpose. In particular, a specific statistical processing software allowed us to determine the values of regression and correlation coefficients with the aim of assessing whether a link exists between the structure of the local tourism supply and the performance recorded in terms of overnights and generated tourist spending.

The analysis was carried out separately for the UNESCO natural and cultural sites to take into account the territorial and morphological differences existing between the two types of site.

In particular, in terms of supply, the following figures relating to the year 2014 were considered for both types of site:

(1) Number of accommodation facilities existing in the local territory (ATECO 55);

(2) Number of catering businesses (ATECO 56); 
(3) Number of car, sports equipment, and bicycle rentals (ATECO 77.11 excluding rental or leasing of cars and other light motor vehicles with driver; ATECO 77.21 excluding rental of pleasure and sailing boats with crew, video tape and record rentals, rental services of other personal and household goods, hire of leisure and recreational equipment and goods supplied by recreational facilities; ATECO 77.39);

(4) Number of travel agencies and tour operators (ATECO 79);

(5) Number of creative, artistic, and entertainment businesses (ATECO 90);

(6) Number of libraries, archives, museums, and other cultural businesses (ATECO 91);

(7) Number of sports, leisure, and entertainment businesses (ATECO 93);

(8) Number of watch, jewelry, and crafts retailers (ATECO 47.77);

(9) Number of other related undertakings without business code.

The UNESCO cultural heritage sites considered in the analysis are the following:

(1) Aeolian Islands-year of inclusion 2000;

(2) Mount Etna-year of inclusion 2013.

In terms of the number of enterprises, the composition of the tourist supply at the two sites is the following:

Table 1

The Composition of the Tourist Supply at the Two Sites

\begin{tabular}{llll}
\hline Type of business & Mount Etna & Aeolian Islands & Total \\
\hline Accommodation facilities & 299 & 261 & 560 \\
Catering activities & 598 & 127 & 725 \\
Car, sports equipment, and bicycle rentals & 11 & 11 & 22 \\
Travel agencies and tour operators & 41 & 11 & 52 \\
Creative, artistic, and entertainment businesses & 3 & 0 & 3 \\
Libraries, archives, museums, and other cultural businesses; & 2 & 0 & 2 \\
Sports, leisure, and entertainment businesses & 66 & 7 & 73 \\
Watch, jewelry, and crafts retailers & 66 & 3 & 69 \\
Other related undertakings without business code & 3 & 6 & 9 \\
\hline
\end{tabular}

Source: Official data (2014) processed by OTIE.

The calculations of the regression coefficients show a perfect fit for the final model, whose dependent variable is represented by the number of overnights. The only type of enterprises considered in the calculation of the angular coefficient is "Other related undertakings without business code", while all the others were excluded because they are characterized by a tolerance value equal to zero and therefore statistically not significant.

\begin{tabular}{|c|c|c|c|c|c|c|c|c|c|}
\hline \multicolumn{10}{|c|}{ Coefficients $^{\mathrm{a}}$} \\
\hline \multirow[t]{2}{*}{ Model } & & $\begin{array}{r}\text { Non-stan } \\
\text { coeffi } \\
\end{array}$ & $\begin{array}{l}\text { lardized } \\
\text { ients }\end{array}$ & $\begin{array}{l}\text { Standardized } \\
\text { coefficients }\end{array}$ & $t$ & Sign. & \multicolumn{3}{|c|}{ Correlations } \\
\hline & & $\mathrm{B}$ & Std. error & Beta & & & Zero order & Partial & Part \\
\hline & (Constant) & $267,704.000$ & 0.000 & & & . & & & \\
\hline 1 & $\begin{array}{l}\text { other related } \\
\text { undertakings without } \\
\text { business code }\end{array}$ & $4,740,280.000$ & 0.000 & 1.000 & . & . & 1.000 & 1.000 & 1.000 \\
\hline
\end{tabular}

Note. a. Dependent variable: Overnights. 
The ANOVA table also confirms that the variability in the overnights can be explained entirely by the observed variables.

However, a further analysis was carried out to overcome the limits of linear regression and curve estimation was applied to carry out the non-linear regression analysis and build a basis to make forecasts. The study was carried out considering separately a linear approximation function and a growth function, in addition to a dependent variable consisting in the overnights or tourist spending. The summary tables of the model follow below.

Linear function with overnights dependent variable:

\begin{tabular}{|c|c|c|c|c|c|}
\hline \multicolumn{6}{|c|}{ Model summary } \\
\hline $\mathrm{R}$ & R-squared & & Adjusted R-squared & \multicolumn{2}{|c|}{ Std. error of the estimate } \\
\hline 1.000 & 1.000 & & . & \multicolumn{2}{|l|}{. } \\
\hline \multicolumn{6}{|c|}{ The independent variable is accommodation facilities. } \\
\hline \multicolumn{6}{|c|}{ Coefficients } \\
\hline & \multicolumn{2}{|c|}{ Non-standardized coefficients } & $\begin{array}{l}\text { Standardized } \\
\text { coefficients }\end{array}$ & \multirow[t]{2}{*}{$t$} & \multirow[t]{2}{*}{ Sign. } \\
\hline & $\mathrm{B}$ & Std. error & Beta & & \\
\hline Accommodation facilities & $-2,724,743.627$ & 0.000 & -1.000 & . & . \\
\hline (constant) & $1,867,089.813$ & 0.000 & & . & . \\
\hline
\end{tabular}

Linear function with tourist spending dependent variable:

\begin{tabular}{|c|c|c|c|c|c|}
\hline \multicolumn{6}{|c|}{ Model summary } \\
\hline $\mathrm{R}$ & \multicolumn{2}{|l|}{ R-squared } & Adjusted R-squared & \multicolumn{2}{|c|}{ Std. error of the estimate } \\
\hline 1.000 & \multicolumn{2}{|l|}{1.000} & . & \multicolumn{2}{|l|}{. } \\
\hline \multicolumn{6}{|c|}{ The independent variable is accommodation facilities. } \\
\hline \multicolumn{6}{|c|}{ Coefficients } \\
\hline & \multicolumn{2}{|c|}{ Non-standardized coefficients } & $\begin{array}{l}\text { Standardized } \\
\text { coefficients }\end{array}$ & \multirow[t]{2}{*}{$t$} & \multirow[t]{2}{*}{ Sign. } \\
\hline & $\mathrm{B}$ & Std. error & Beta & & \\
\hline Accommodation facilities & $-8,651,061.014$ & 0.000 & -1.000 & . & . \\
\hline (constant) & $5,928,010.157$ & 0.000 & & . & . \\
\hline
\end{tabular}

Growth function with overnights dependent variable:

\begin{tabular}{|c|c|c|c|c|c|}
\hline \multicolumn{6}{|c|}{ Model summary } \\
\hline $\mathrm{R}$ & \multicolumn{2}{|l|}{ R-squared } & Adjusted R-squared & \multicolumn{2}{|c|}{ Std. error of the estimate } \\
\hline 1.000 & \multicolumn{2}{|l|}{1.000} & . & \multicolumn{2}{|l|}{. } \\
\hline \multicolumn{6}{|c|}{ The independent variable is accommodation facilities. } \\
\hline \multicolumn{6}{|c|}{ Coefficients } \\
\hline & \multicolumn{2}{|c|}{ Non-standardized coefficients } & $\begin{array}{l}\text { Standardized } \\
\text { coefficients }\end{array}$ & \multirow[t]{2}{*}{$-t$} & \multirow[t]{2}{*}{ Sign. } \\
\hline & $\mathrm{B}$ & Std. error & Beta & & \\
\hline \multirow{2}{*}{$\begin{array}{l}\text { Accommodation facilities } \\
\text { (constant) }\end{array}$} & -7.290 & 0.000 & -1.000 & & . \\
\hline & 16.777 & 0.000 & & . & . \\
\hline
\end{tabular}

The dependent variable is $\ln$ (overnights). 
Growth function with tourist spending dependent variable:

\begin{tabular}{|c|c|c|c|c|c|}
\hline \multicolumn{6}{|c|}{ Model summary } \\
\hline $\mathrm{R}$ & \multicolumn{2}{|l|}{ R-squared } & Adjusted R-squared & \multicolumn{2}{|c|}{ Std. error of the estimate } \\
\hline 1.000 & \multicolumn{2}{|l|}{1.000} & . & $\cdot$ & \\
\hline \multicolumn{6}{|c|}{ The independent variable is accommodation facilities. } \\
\hline \multicolumn{6}{|c|}{ Coefficients } \\
\hline & \multicolumn{2}{|c|}{ Non-standardized coefficients } & $\begin{array}{l}\text { Standardized } \\
\text { coefficients }\end{array}$ & \multirow[t]{2}{*}{$t$} & \multirow{2}{*}{ Sign. } \\
\hline & $\mathrm{B}$ & Std. error & Beta & & \\
\hline \multirow{2}{*}{$\begin{array}{l}\text { Accommodation facilities } \\
\text { (constant) }\end{array}$} & -7.290 & 0.000 & -1.000 & . & . \\
\hline & 17.932 & 0.000 & & . & . \\
\hline
\end{tabular}

The dependent variable is $\ln$ (tourist spending).

The variations in the number of accommodation facilities fully explain the changes in the number of overnights and in generated tourist spending. This means that the role they play at these sites is essential within the local tourist supply. They constitute, therefore, a key element to leverage in order to amplify the economic effects of overnights throughout a given area.

Finally, the calculation of the correlations between the various types of enterprises and tourist spending allows you to check whether there is a link between the observed variables. However, it should be noted that the existence of such a link between the investigated variables does not offer an explanation in terms of cause and effect. Generally, in the case of the observed natural sites, there appears to be a very strong link between the number of enterprises and the number of overnights recorded.

The analyses have allowed us to determine the relationship existing between the supply structure and the performance recorded at the UNESCO sites considered.

In some cases, despite the fact that there is no directly proportional relationship between the individual variables considered, the final overall result showed that they did exist.

It is very likely that the problem is due to the fact that the considered variables are strongly correlated between them and the observed dependency relation is not the only one possibility. These aspects can partially distort the results while providing, though, an overall picture that reflects the initial assumptions and what has been observed in general.

It is certainly important to highlight that the facilities and infrastructures presented in a given area can affect the overnights, thus constituting almost an attraction. This is confirmed by the fact that the presence of undertakings engaged in an efficient and effective way in providing services to visitors encourages the latter not only to come to a particular location, but also to stay there, transforming each arrival into an overnight.

\section{Conclusions and Limitations}

Despite the limitations of our analysis, in the Sicilian case, there seems to be proof of the existence of a positive correlation between designation as WHL natural site and an increase in tourist demand. Therefore, it might seem that our work follows the current of thought that considers the existence of a positive correlation between inclusion on the UNESCO WHL and an increase in the tourist demand. However, the findings of the ANOVA model demonstrate a more positive correlation in WHL sites where territories have a good and well-structured supply, i.e., there is a significant relationship between the structure and quantitative 
characteristics of the tourism supply at UNESCO natural sites in Sicily and the performance recorded in terms of overnights and generated tourist spending. Our main conclusion is related to the possibility that these effects on tourism from inclusion on the WHL are more effective if territories have a tourism supply chain structure.

Broadly speaking, in the Sicilian case, WHL designation seems to act more as a passive inductor of tourism than as a true driver. So, we can consider the UNESCO WHL as a necessary but not sufficient condition to transform a natural site (in our case) into a tourist destination. This leads us to hold a conceptually prudent position that would fit better within the current of ambiguous thinking. Put otherwise, we believe that the WHL brand has only an indirect effect on tourism.

Our study suggests that there is a need to set up a supply structure consisting primarily of private economic operators involved in various capacities in the sector, which is both quantitatively and qualitatively adequate and capable of drawing visitors and making them stay overnight or extend their stay.

As already highlighted in the introduction, in order for a site to make the transition from tourist attraction to tourist destination, it is not enough to have well-known cultural or natural assets (Cellini \& Cuccia, 2013) like those that are included on the World Heritage List. It is necessary to build the infrastructure and necessary structures for inclusion in an integrated system. It is necessary to make the assets accessible and not simply reachable and to make visitors enjoy an asset and not just exploit it. Therefore, it is important to start from the renovation of accommodation facilities and of the other enterprises that operate or are anyway involved in the tourism sector, and then to increase the number of active units starting from those with the highest level of correlation in terms of overnights and tourist spending.

All this should be pursued in the context of harmonious, sustainable, and long-term tourism and local development while respecting local environmental and cultural features. This will allow drawing a greater number of visitors through the promotion of a destination as an integrated system of goods and services, while reducing seasonality and extending the tourist season to the buffer months immediately before and after high season.

This will also help reduce the pressure exerted by tourism. In the case of sites located near the coast, there is a concentration of overnights mainly during the summer months. However, the characteristics of the natural heritage considered, especially with reference to volcanoes sites, do not warrant this temporal concentration and indeed provide for the necessary and sufficient prerequisite conditions to launch deseasonalization policies that need to involve the structures available at the site and supply as a whole.

The presence of tourism supply in a territory that decides to apply to be part of the WHL could act as an accelerator to increase the effects in terms of tourism economics, as opposed to other territories poor in tourism supply. Apart from the presence or absence of supply in quantitative and qualitative terms, it is necessary to develop activities and events that can draw the attention of tourists and convince them to reach Sicily's UNESCO sites. As suggested by the study, entertainment activities play a key role. These constitute the first step along a pathway to upgrade the local tourism supply. They can both attract tourists and affect their propensity to spend, thus having beneficial effects both on the number of overnights and on the overall economy of the territory.

Enterprises, therefore, have the necessary means to drive the development of a site by transforming it from a mere attraction into a tourist destination with an integrated and efficient supply. This would have a positive impact on the entire supply chain by setting in motion a virtuous circle driven by the private initiative of players operating in the sector. These positive effects must also result in investments for both the structural 
upgrading of the supply and for the creation of new territorial and tourism marketing strategies.

\section{References}

Arezki, R., Cherif, R., \& Piotrowski, J. M. (2009). Tourism specialization and economic development: Evidence from the UNESCO world heritage list. No. 2009-2176. International Monetary Fund.

Behncke, B. (2009). Hazards from pyroclastic density currents at Mt.Etna (Italy). Journal of Volcanology and Geothermal Research, 180, 148-160.

Buckley, R. (2004). The effects of World Heritage Listing on tourism to Australian National Parks. Journal of Sustainable Tourism, 12(1), 70-84.

Carracedo, J. (2006). El volcán Teide: Volcanología, interpretación de paisajes e itinerarios comentados. Tenerife: Cajacanarias.

Cellini, R. (2011). Is Unesco recognition effective in fostering tourism? A comment on Yang, Lin and Han. Tourism Management, 32(2), 452-454.

Cellini, R., \& Cuccia T. (2013). Museum and monument attendance and tourism flow: A time series analysis approach. Applied Economics, 45(24), 3473-3482.

Cuccia, T., Guccio, C., \& Rizzo, I. (2014). Does UNESCO inscription play a significant role in tourism destinations performance? Evidence from the Italian regions, Catania.

Dóniz Páez, F. J., Guillén, C., Becerra Ramírez, R., \& Kereszturi, G. (2010). Volcanes y turismo: Patrimonio, atractivo, recurso y producto. Turismo, 2, 73-79.

Dóniz Páez, F. J. (2014). Reflexiones en torno al turismo volcánico. El caso de Islas Canarias. PASOS. Revista de Turismo y Patrimonio Cultural, 12(2), enero-abril, 467-478.

Dowling, R. K. (2009). Geotourism’s contribution to local and regional developmen. In C. de Carvalho and J. Rodrigues (Eds.), Geotourism and local development (pp. 15-37). Camara Municipal de Idanha-a-Nova, Portugal.

El Wartiti, M., Malaki A., Zahraoui M., Di Gregorio F., \& De Waele J. (2009). Geosites and touristic development of the north-western Tabular Middle Atlas of Morocco. In A. Marini (Ed.), Proceedings of desertification and risk analysis using high and medium resolution satellite data (pp. 143-159). Tozeur, Tunesia: Springer Netherlands.

Erfur-Cooper, P., \& Cooper, M. (Eds.). (2010). Volcano and geothermal tourism: Sustanible geo-resources for leisure and recreation. London: Earthscan Publications.

Erfur-Cooper, P. (2010). Volcano tourism: A growing demand for active volcanoes and geothermal destinations. 6th cities on volcanoes. Abstracts volume. Tenerife.

Erfur-Cooper, P. (2011). Geotourism in Volcanic and Geothermal Environments: Playing with Fire? Geoheritage, 3, 187-193.

Farsani, T. N., Coelho, C., \& Costa, C. (2009). Geotourism as an opportunity for local communities' participation in geoparks. In Proceedings of 8th European Geoparks Conference, Idanha-a-Nova, Geopark Naturtejo, Portugal, September.

Farsani, T. N., Coelho, C., \& Costa, C. (2011). Geotourism and geoparks as novel strategies for socio-economic development in rural areas. International Journal of Tourism Research, 13, 68-81.

Fredman, P., Friberg, L. H., \& Emmeling, L. (2007). Increased visitation from national park designation. Current Issues in Tourism, 10(1), 87-95.

Frediani, F. (2001). Un “patrimonio” per lo sviluppo turistico. Rivista del Turismo, No. 5/6.

Frey, S. B., \& Steiner, L. (2011). World heritage list: Does it make sense? International Journal of Cultural Policy, 17(5), 555-573.

Frey, B., Pamini P., \& Steiner, L. (2013). Explaining the world heritage list: An empirical study. Spinger.

Gerner, D., Rybár, P., Engel, J., \& Domaracká, L. (2009). Geotourism marketing in lake constance’ region. Acta Montanistica Slovaca, 14(2), 197-204.

Gray, M. (2008). Geodiversity: Developing the paradigm. Proceedings of the Geologists’ Association, 119(3), 287-298.

Hansell, A., \& Oppenheimer, C. (2004). Health hazards from volcanic gases: A systematic literature review. Arch Environ Health, 59, 628-639.

Heggie, T. W. (2009). Geotourism and volcanoes: Health hazards facing tourists at volcanic and geothermal destinations. Travel Medicine and Infectious Disease, 7, 257-261.

Hose, T. A. (2007). Geotourism in Almeria Province, southeast Spain. Tourism, 55(3), 259-276. 
Joyce, B. (2010). Volcano tourism in the New Kanawinka global geopark of Victoria and SE South Australia. In P. Erfurt-Cooper and M. Cooper (Eds.), Volcano and geothermal tourism: Sustanible geo-resources for leisure and recreation (Chapter 20, pp 302-311). London: Earthscan Publications.

Lai, A. (2013). What's the big deal about having a UNESCO world heritage site? http://travel.cnn.com/hong-kong-world-heritage-site-020521

Lane, L. R., Tobin, G. A., \& Whiteford L. M. (2003). Volcanic hazard or economic destitution: Hard choices in Banos, Ecuador. Environ Hazards, 5, 23-34.

Lazzarotti, O. (2000). Patrimoine et tourisme: Un couple de la mondialisation. Mappemonde, 15, 12-16.

Leask, A., \& Fyall, A. (Eds.). (2006). Managing world heritage sites. Routledge.

Lopes-Gautier, R. (2010). Volcanoes for the non-profesional: Encouraging tourism and education. 6th cities on volcanoes. Abstracts volume. Tenerife.

Lo Piccolo, F., \& Leone, D. (2014). From planning to management of cultural heritage sites: Controversies and conflicts between UNESCO WHL management plans and local spatial planning in South-Eastern Sicily. European Spatial Research and Policy, 21(2), 47-65.

Mc Keever, P., Larwood, J., \& McKirdy, A. (2006). Geotourism in Ireland and Britain. In D. Newsome and R. Dowling (Eds.), Geotourism (pp. 180-198). Oxford: Elsevier.

Mc Keever, P., Zouros, N., \& Patzak, M. (2010). The UNESCO global network of national geopark. In D. Newsome and R. Dowling (Eds.), Geotourism: The tourism of geology and landscape. Oxford: Good Fellow Publishers.

Mollaei, H., Torshizian, H., \& Sharifi, E. (2010). Sabalan volcano lake: An example of geotourism potential in Iran. 6th cities on volcanoes. Abstracts volume. Tenerife.

Mondini, G., \& Re, A. (2012). Monitoring the management's impacts of UNESCO world heritage sites (No. 201205). University of Turin.

National Geographic Society. (2005). The geotourism approached. Available at http://www.innovasjonnorge.no/Reiseliv_fs/PDF/Foredrag\%20Tourtellot-2.pdf

Newsome, D., \& Dowling, R. (2010). Setting an agenda for geotourism. In D. Newsome and R. Dowling (Eds.), Geotourism: The tourism of geology and landscape. Oxford: Good Fellow Publishers.

O’Connor, P. J. (2008). The role of geotourism in supporting regeneration in disadvantaged rural communities in Ireland, Sustainable Tourism III. In Proceedings of 3rd International Conference on Sustainable Tourism (pp. 267-275). Malta, Spain: WIT PRESS. Southampton.

Patuelli, R., Mussoni, M., \& Candela, G. (2012). The effects of world heritage sites on domestic tourism: A spatial interaction model for Italy. Quaderni-Working Paper DSE No. 834.

Patzak, M., \& Eder, W. (1998). UNESCO geopark: A new programme-a new UNESCO label. Geologica Balkanica, 28(3-4), 33-34.

Poria, Y., Reichel, A., \& Cohen, R. (2013). Tourists perceptions of world heritage site and its designation. Tourism Management, 35, 272-274.

Rodwell, D. (2002). The world heritage convention and the exemplary management of complex heritage sites. Journal of Architectural Conservation, 3, 40-60.

Roh, T. S., Bak, S., \& Min, C. K. (2015). Do UNESCO heritages attract more tourists? World, 6(1).

Shackley, M. (1998). Introduction-World cultural heritage sites. In M. Shackley (Eds.), Visitor management: Case studies from world heritage sites (pp. 1-9). Oxford: Butterworth-Heinemann.

Sheth, H., Ray, J., Bhutani, R., Kumar, A., \& Awasthi, N. (2010). The latest (2008-09) eruption of Barren Island volcano, and some thoughts on its hazards, logistics and geotourism aspects. Current Science, 98(5), 620-662.

Sigurdson, H., \& Lopes-Gautier, R. (2000). Volcanoes and tourism. In Sigurdson (Ed.). Encyclopedia of volcanoes (pp.1283-1299). San Diego: Acadmic Press.

Strasser, P. (2002). Putting reform into action-Thirty years of the world heritage convention: How to reform a convention without changing its regulations. International Journal of Cultural Property, 11(2), 215-266.

Timothy, D. J., \& Boyd, S. W. (2003). Heritage tourism. UK: Pearson Education.

Toulkeridis, T., \& Zak, V. (2010). Volcanic Caldera Lake Cuicocha in Ecuador and associated scientific tourism. 6th cities on volcanoes (pp. 205). Tenerife.

Tucker, H., \& Emge, A. (2010). Managing a world heritage site: The case of Cappadocia. An International Journal of Tourism and Hospitality Research, 21(1), 41-54. 
UNESCO. (2006a). Guidelines and criteria for national geoparks seeking UNESCO's assistance to join the global geoparks network. Paris. Internal document.

UNESCO. (2006b). Global geoparks network. UNESCO Division of Ecological and Earth Sciences. Section Geoparks Secretariat. Available at http://unesdoc.unesco.org/images/0015/001500/150007e.pdf

Van der Aa, B. J. M. (2005). Preserving the heritage of humanity? Obtaining world heritage status and the impacts of listing. Amsterdam: Netherlands Organization for Scientific Research.

Yang, C. H., Lin, H. L., \& Han, C. C. (2010). Analysis of international tourist arrivals in China: The role of world heritage sites. Tourism Management, 31, 827-837.

Zouros, N., \& Martini, G. (2003). Introduction to the European geoparks network. In NHM of Lesvos Petrified Forest (pp. 17-21), Proceedings of the 2nd International Symposium of Natural Monuments and Geological Heritage. Natural History Museum of the Lesvos Petrified Forest: Lesvos, Greece: Lesvos. 